\title{
Fibrosis in chronic viral hepatitis
}

\author{
Vincenza Calvaruso, MD, PhD*, Antonio Craxì, Professor of Gastroenterology
}

Sezione di Gastroenterologia ed Epatologia, Di.Bi.M.I.S., University of Palermo, Piazza delle Cliniche n.2, 90127 Palermo, Italy

\section{Keywords:}

Viral chronic hepatitis

Anti-viral therapy

liver fibrosis
In the last years, several studies have been performed with the aim to evaluate the real impact of antiviral treatments on fibrosis progression in patients with chronic viral hepatitis.

The main goal of therapy in patients with chronic hepatitis B is viral suppression. This outcome leads to an important improvement in both hepatic inflammation and fibrosis and reduces the HCC occurrence. An histological improvement has been largely demonstrated in patient treated with oral nucleoside and nucleotide analogs achieving the rate of $72 \%$ with entecavir and tenofovir.

Similarly, in patients with chronic hepatitis C, sustained virologic response to interferon therapy is associated with regression of fibrosis and lower liver decompensation and HCC occurrence.

In the next future further studies will assess the real impact of the new directly anti-viral agents on liver necroinflammation and fibrosis in chronic hepatitis $\mathrm{C}$.

(c) 2011 Elsevier Ltd. All rights reserved.

\section{Introduction}

Liver fibrosis is a common complication of chronic viral hepatitis leading to the progressive destruction of normal tissue architecture or the replacement of hepatocytic tissue with fibrous tissue. The final outcome of this process is liver cirrhosis, which is the major cause of morbidity and mortality in chronic viral hepatitis. Fibrogenesis is closely related to activation of the main type of fibrocompetent cells in the liver: hepatic stellate cells. Experimental models have allowed a better understanding of the dynamics of fibrosis, the biological processes related to its progression and regression and the development of new anti-fibrotic drugs. However, the role of interferon-based and

\footnotetext{
* Corresponding author. Tel.: +39 0916552280; fax: +39 0916552156.

E-mail address: vcalvaruso@libero.it (V. Calvaruso).
} 
not antiviral therapy has been demonstrated and the impact of these treatment in patients with chronic viral hepatitis on fibrosis progression in comparison with the natural history of these disease remain an important issue to assess. This review collects the literature data published so far.

\section{Chronic HBV infection}

\section{Epidemiology and incidence of fibrotic evolution to cirrhosis}

Between 350 million and 400 million persons worldwide are chronically infected with hepatitis B virus (HBV) [1]. The two primary adverse outcomes of chronic infection are hepatocellular carcinoma (HCC) and cirrhosis, either of which can lead to a liver-related death. The annual incidence of cirrhosis in patients with CHB has been estimated at 1.3-2.4\% [2] and although the cumulative 5-year survival rate for patients with compensated cirrhosis is $84 \%$ [3], in patients with decompensated cirrhosis, this declines to $14-35 \%[3,4]$.

A number of studies have examined predictors of progression to advanced fibrosis [5-9] and considerable attention has been focused on a large, prospective recent study of the incidence of cirrhosis in CHB [10]. This study followed 3582 subjects for a mean of 11 years and reported that cirrhosis was strongly correlated with the level of circulating virus, with an increasing incidence of cirrhosis being found in patients with higher levels of virus at entry into this study. It should be noted that $85 \%$ of this cohort was HbeAg-negative and this study was restricted to patients over 30 years of age.

The current literature in HBeAg-positive patients does not support an association between HBV DNA and fibrosis. Two studies of over 300 predominantly HBeAg-positive patients did not find HBV DNA to be a predictor of fibrosis [11,12], suggesting that lower HBV DNA, reflecting an increased immune response, is correlated with fibrosis.

Similar results have been found by Wang et al [13] who studied 28 HBeAg-positive, immunetolerant patients and reported that lower serum HBV DNA level, along with age 430 years, was independently correlated with stage 2 fibrosis or more on liver biopsy.

\section{Mechanisms and features of fibrosis}

In chronic HBV infection, liver damage appears to be immune-mediated, with HBV-specific T cells playing a key role both in disease pathogenesis and viral clearance. The inflammatory infiltrates of chronic hepatitis B shows similar cellular composition of the chronic hepatitis C, with CD4-positive T cells predominating over CD8-positive T cells [14].

When the HBV-specific CD8 response is unable to control virus replication, it may contribute to liver pathology not only directly, but also by causing recruitment of non-virus-specific T cells [15] which have an aberrant functional profile and may impede proliferative anti-viral effector function, while contributing to the proinflammatory cytokine environment [16]. Furthermore, NK cells may also cause hepatocyte death by a non-antigenspecific mechanism [17].

In chronic hepatitis B, there is a varying degree of predominantly lymphocytic portal inflammation with interface hepatitis and spotty lobular inflammation.

Inflammation is minimal in the immune-tolerant and inactive carrier phases, but is prominent in the immunereactive phase. Bridging necrosis is identified as inflammation 'connecting' portal tracts to one another or to central veins and confluent necrosis affects multiple contiguous hepatocytes. Inflammation is typically associated with scarring, which can vary from a mild portal expansion to periportal fibrous strands, bridging fibrosis, and cirrhosis. A typical histological feature of chronic hepatitis B is 'ground-glass' cytoplasm of the hepatocytes rich in hepatitis B surface antigen (HBsAg) [18].

\section{Impact of HBeAg seroconversion to Anti-HBe on liver fibrosis}

The loss of HBeAg is associated with a fall in HBV DNA to low levels (generally $<1000 \mathrm{IU} / \mathrm{mL}$ ), normalization of serum ALT levels, and resolution of active necroinflammatory injury on liver biopsy. Histological studies based on paired biopsies obtained before and after HBeAg seroconversion have consistently demonstrated that seroconversion to antibody to $\mathrm{HBeAg}$ (anti-HBe) is followed by 
a significant improvement or even disappearance of disease activity and this improvement seems to be irrespective of the extent of the liver damage in the baseline biopsy, indicating that liver histology during the HBeAg-positive phase is not predictive of the late outcome of liver disease [19]. When sustained, these changes are associated with excellent long-term prognosis [20]. Unfortunately, loss of $\mathrm{HBeAg}$ with or without HBeAg seroconversion is not always associated with resolution of disease. Infact, in some patients, HBeAg reappears in the serum once treatment is withdrawn and the disease returns to its initial level of activity. In other patients, virological, biochemical, and clinical relapse of disease occurs without reappearance of $\mathrm{HBeAg}$ (HBeAg-negative chronic hepatitis B), which may be as severe as HBeAg-positive disease.

Relapse in disease either due to return of HBeAg or evolution into HBeAg-negative hepatitis appears to be more common in responders to oral nucleoside analogue therapy than in those responding to interferon or peginterferon and recent data suggest that a fall in HBeAg concentration during peginterferon therapy predicts subsequent HBeAg loss [21].

\section{Impact of Serum HBV DNA suppression}

Serum HBV DNA levels reflect the level of hepatic HBV replication but do not necessarily indicate the presence of ongoing HBV-related liver injury.

However, the observation that patients in with HBV DNA concentrations $>10^{5}$ copies $/ \mathrm{mL}$ $(\sim 20,000 \mathrm{IU} / \mathrm{mL})$ were at increased risk of HCC (odds ratio $=8.9)$ has led some to suggest that viral suppression should be the main goal of therapy for all patients, irrespective of other factors [22]. Infact, with suppression of viral replication, liver biochemistry, and more importantly, histology, both inflammation and fibrosis improve.

\section{Mechanisms and impact of anti-viral treatment}

In chronic hepatitis B, complete eradication of hepatitis B virus (HBV) infection is rarely achieved with currently available therapies. Even in those who clear HBsAg, HBV remains in infected hepatocytes in the form of covalently closed circular DNA (cccDNA) likely for the lifetime of the cell if not the individual, thus making it possible for reactivation to occur with the right stimulus [23].

Thus, the goal of therapy is to prevent the development of cirrhosis that greatly increases the risk of HCC and the other complications of advanced liver disease. However the progression to these clinically relevant endpoints is slow, generally requiring years or decades to become evident and then they are impractical targets to assess therapy. Thus potential therapeutic surrogate endpoints include clinical, biochemical, virological, serological, or histological improvement.

\section{Alpha interferon benefits}

Alpha interferon acts by inducing an anti-viral state in cells, through engagement of cell surface receptors and subsequent activation of pathways that lead to increased expression of intracellular genes that cause an increase in breakdown in viral RNAs and protection against viral injury [24].

Alpha interferon also stimulates cell-mediated immune responses which target infected hepatocytes leading to a decrease in cells that harbour the intrahepatic, HBV covalently closed circular DNA (cccDNA) molecules responsible for persistence of HBV infection.

In the last years there has been an increased interest based on results demonstrating the peginterferon has more potent anti-viral activity than standard alpha interferon and, in contrast to nucleoside analogues, does not result in anti-viral resistance and can be given for a finite period rather than indefinitely [25].

Three large clinical trials of peginterferon have convincingly demonstrated that a loss of $\mathrm{HBsAg}$ after anti-viral therapy was confined to patients receiving peginterferon, either alone or in combination [26-28].

HBsAg clearance has been reported to occur less commonly in HBeAg-negative hepatitis, reflecting the generally lower rates of sustained virological response with this disorder and perhaps differences 
in immune features and duration of infection among patients who are HBeAg-negative compared to those who are HBeAg-positive [29,30].

\section{Analogues Therapy Benefits}

The use of oral nucleoside and nucleotide analogues have revolutionized the management of chronic hepatitis B. Five different anti-viral agents have been approved and the treatment with these oral agents has been shown to be life-saving.

Such therapy can not only retard the progression of fibrosis and reverse both fibrosis and cirrhosis [31-36], but also salvage patients with decompensated chronic hepatitis B [37-39] and prevent hepatic decompensation in patients with advanced fibrosis and cirrhosis [40].

\section{Lamivudine}

Lamivudine is the first oral agent licensed for treatment of hepatitis B. Clinical trials have been shown that Lamivudine therapy is able to retard the progression of fibrosis, reduce progression to and reverse cirrhosis, salvage and stabilize patients with hepatic decompensation (delaying or averting liver transplantation), and, in patients with advanced fibrosis and cirrhosis, to prevent hepatic decompensation $[31,34,37,38,40]$.

Although lamivudine has the most extensive safety record, its current use is limited by the high frequency of lamivudine resistance (up to $30 \%$ in year 1 and up to $70 \%$ by the end of 5 years) [41] and the availability of more potent agents with superior efficacy and markedly improved resistance profiles.

\section{Adefovir}

Adefovir is less potent than lamivudine and the other more recently introduced oral agents but the advantage of this drug is its limited resistance during 1-2 years, the absence of cross-resistance with lamivudine and other L-nucleosides and, therefore, its value as treatment for lamivudine-resistant chronic hepatitis B $[42,43]$ and for hepatic decompensation associated with lamivudine resistance prior to and after liver transplantation [44].

Moreover, although resistance to adefovir is slow to emerge, resistant variants increase progressively after the first year, reaching almost 30\% by the end of 4 years [45].

\section{Entecavir}

Entecavir inhibits HBV DNA priming, reverse transcription of negative stranded HBV DNA and synthesis of positive-strand HBV DNA and has profound activity against HBV. Therapy with entecavir was associated with a more frequent fall of HBV DNA to undetectable levels $\left(<10^{2} \log 10\right.$ copies $/ \mathrm{mL}$ ) than lamivudine, in $67 \%$ versus $36 \%$ of patients who were $\mathrm{HBeAg}$-positive and in $90 \%$ versus $72 \%$ in patients who were $\mathrm{HBeAg}$-negative.

Histological improvement was achieved in $72 \%$ of entecavir-treated patients compared to $62 \%$ in lamivudine-treated patients with HBeAg; and in $70 \%$ of entecavir-treated versus $62 \%$ of lamivudinetreated patients in those who were HBeAg-negative [46,47].

Recently, the impact on liver inflammation and fibrosis in patients who received at least 3 years of cumulative entecavir therapy has been evaluated. The authors found that $96 \%$ of the patients with CHB who were treated with entecavir in this long-term cohort achieved substantial histological improvement and regression of fibrosis or cirrhosis [48].

\section{Telbivudine}

There is a paucity of data on the real effects of telbivudine on histological improvement in patients with chronic hepatitis B. In HBeAg-positive patients, telbivudine seems to be superior to lamivudine in suppressing HBV DNA to undetectable levels, $<10^{2}$ copies/mL (60\% versus $40 \%$ ), and in achieving histological improvement (65\% versus 56\%) but not in biochemical (77\% versus75\%) or serological responses (HBeAg seroconversion in $23 \%$ versus $22 \%$ ). However, in HBeAg-negative patients, telbivudine was superior to lamivudine in suppressing HBV DNA to undetectable levels (88\% versus $71 \%$ ) but not in achieving histological (67\% versus $66 \%$ ) or biochemical improvement (74\% versus $79 \%$ ) [49]. 
Tenofovir

Tenofovir is the most recently approved drug for hepatitis B and at recommended oral doses is more potent, more rapidly acting, and has a better resistance profile and an excellent safety profile than adefovir [50].

Licensed initially for the treatment of human immunodeficiency virus (HIV), either as monotherapy or in a single-pill combination with emtricitabine, tenofovir has excellent anti-viral activity against hepatitis $B$ in patients with HIV/HBV coinfection as well as in patients with HBV monoinfection.

One of the most important advantages of this drug is the HBsAg seroconversion obtained in $3 \%$ of patients during the first 48 weeks of therapy [50] which increased, at the end of year 2 of continuous tenofovir treatment, to 6\% [51]. In HBeAg-negative patients, at the end of year 1 of therapy, tenofovir suppressed HBV DNA to $<10^{2} \mathrm{IU} / \mathrm{mL}$ in $95 \%$ of patients, compared to $64 \%$ in the adefovir group and histological improvement was observed in $72 \%$ of the tenofovir-treated subjects. Also for tenofovir, further studies will assess the real impact of this 'newer' oral agent on liver fibrosis related to HBV.

\section{Chronic HCV infection}

\section{Epidemiology and incidence of progression to cirrhosis}

In the Western world HCV infection is the major cause of cirrhosis and hepatocellular carcinoma (HCC), the main cause of liver-related deaths and the most common indication for liver transplantation (OLT) [52-56]. There are approximately 170 million carriers of chronic HCV worldwide, but probably most of them are not identified [57]. Among patients, more than 30 million are affected by cirrhosis and about 1-2 million new HCC cases are discovered each year.

Although a test for HCV was available since 1989 [58], the natural history of this chronic infection is only partially understood, and its evolution to liver cirrhosis is very variable.

Many factors, either virus-related or host-related, have been investigated in order to understand the natural history of this infection. The biochemistry is only partially indicative of the evolution because chronic infection could develop with abnormal alanine aminotransferase (ALT) levels in $60 \%-80 \%$ of cases and among subjects with normal ALT levels in 20\%-40\%. In a study on HCV-infected patients with persistently normal aminotransferases levels and mild hepatitis, the biopsy performed after five years showed no progression [59]. About 30\%-50\% of all infected patients develop hepatic fibrosis without clinically and biochemically significant liver disease. As far as the factors related to the virus are concerned, genotype does not correlate with the activity of the disease [60], nor with the outcome [61], although an Italian study found a significant correlation between genotype 1b and risk of HCC [62]. Viral load has no correlation with the histology activity index although it has implications on viral response to anti-viral therapy. However, the presence of other viral infections, like HIV/HBV, speeds up the clinical course of the disease [63-65].

Among the host-related factors, age at infection [66-68], male gender, race, and alcohol consumption of more than $50 \mathrm{gm} /$ day are statistically associated with fibrosis progression [68-70]. Another important aspect that impacts on the evolution of chronic HCV infection is the presence of comorbidities. Obesity, iron overload, environmental factors and non-alcoholic steatohepatitis are important determinants of disease progression [71-75]. Among investigated co-factors determining the natural history of the infection, alcohol is undoubtedly the most relevant risk factor of progression to cirrhosis [76]. There are also geographical differences in the evolution to cirrhosis: in U.S.A. and Europe this percentage is nearly $15 \%$ (range $8 \%-24 \%$ ), while in Japan is much higher, ranging between $30 \%$ and $46 \%$. Similarly, the percentage of evolution to HCC is $0.7 \%-1.3 \%$ in Western countries, but in the Far East and Japan the rate is ranges from $10 \%$ to $19 \%$.

As a matter of fact the most important information comes from studies performed on infection acquired after blood transfusions or after injection with contaminated immunoglobulins. Studies dealing with community-acquired infection could be the most important ones, but the absence of data on the onset of the infection makes it very difficult to outline the true timetable of events. Longterm studies in patients with transfusion-acquired infection indicate that spontaneous recovery occurs in $12 \%-26 \%$ of cases, chronic hepatitis in $40 \%-73 \%$, cirrhosis in $15 \%-23 \%$, and liver-related death after 25 years of follow-up is $4 \%$ (range 3\%-7\%). In these patients, the time interval between the 
infection and the occurrence of chronic hepatitis, cirrhosis and hepatocellular carcinoma was about 10,20 and 30 years, respectively [58,77,78]. The very prolonged course of disease does not allow to assess directly the true endpoints of therapeutic anti-viral efficacy, such as increased survival, therefore, the stable disappearance of indicators of the HCV infection and of necroinflammatory/ fibrogenetic process in the liver is assumed to represent the cure of the disease and is used to the best surrogate endpoint.

Histological lesions provide direct evidence of the activity grade and the fibrosis stage and its trend to progression towards cirrhosis.

Impact of anti-viral treatment on progression of chronic hepatitis $C$ to cirrhosis

Liver biopsy is the best standard to assess the severity of chronic hepatitis $\mathrm{C}$, to define the prognosis and to assess the necroinflammation or the fibrosis modifications. The comparison of histological activity and the stage of fibrosis on biopsies performed before and after anti-viral treatment remains the most reliable parameter to assess short-term benefit of viral clearance [79]. A study from Japan examined whether interferon therapy was associated with regression of histological fibrosis in 487 patients by using paired biopsy samples obtained 1-10 years apart [80]. The results suggest that, in patients with chronic hepatitis $C$, regression of fibrosis is associated with sustained virologic response to interferon therapy. Another European study which analyzed the long-term clinical outcome of chronic hepatitis $C$ patients with sustained virological response concluded that sustained virological response was associated with a decrease in fibrosis score [81]. Similar findings have been reported in sustained responders to pegylated interferon [82,83]. Recently, another study has been performed with the aim to evaluate the long-term histologic outcome of people with SVR after HCV therapy in a large cohort of patients [84]. The authors found that $82 \%$ of the patients had decreased fibrosis scores, and 92\% had decreased inflammation scores on long-term follow-up biopsies, concluding that clinical, virologic, biochemical, and histologic outcomes of patients followed 5 years after SVR are favourable, and recovery of normal or nearly normal liver architecture is possible.

To better define the long-term benefits of anti-viral therapy, we must take into account the likelihood of progression to cirrhosis in treated patients. Available literature data on this issue are scarce $[81,85,86]$. Once SVR is achieved after anti-viral therapy, histological progression is uncommon ( 7 out of $1660,0.43 \%$ ). Instead, in relapsers or non-responders to anti-viral therapy the rate of disease evolution to cirrhosis over 1-13 years is much more frequent (162 out of 2078, $7.7 \%)$.

Impact of anti-viral treatment on progression from compensated to decompensated cirrhosis and hepatocellular carcinoma

Many studies sought to investigate whether SVR, compared to no response, leads to an improved clinical outcome for patients with chronic hepatitis $C$ and advanced fibrosis.

A cohort study concluded that patients with $\mathrm{CHC}$ and advanced fibrosis, SVR reduced complications of liver disease, especially development of liver failure [87], but a significant decrease in incidence of HCC has not found. These findings contrasts with results of studies from Japan, where the benefit of interferon treatment lies mainly in the prevention of HCC $[88,89]$.

A randomised controlled trial (RCT) comparing pegylated interferon monotherapy vs. combination therapy with ribavirin in patients with HCV cirrhosis and portal hypertension to assessed the efficacy and feasibility of anti-viral therapy and explored the role of viral eradication on the clinical course of disease [90]. It has been found that overall rate of SVR was higher in the group of patients receiving ribavirin, although the result was not statistically significant due to inadequate sample size, and it has been concluded that viral eradication was related to a marked improvement in prognosis, since disease deterioration occurred only in 6\% of patients with SVR as compared to $38 \%$ of nonresponders [90].

Bruno et al [91] in a recent study demonstrated that the achievement of SVR abolishes the development of EV in the long-term. These data are also supported by other studies in which the achievement of virological response following anti-viral therapy was associated with a significant decrease of HVPG values [92,93], fibrosis regression [94,95], and reduction of portal hypertensionrelated complications in patients with similar clinical characteristics $[87,96]$. 
Finally, the favourable impact of SVR on the development of HCC has been also demonstrated by Cardoso et al [97] in a cohort of 307 patients with bridging fibrosis or cirrhosis HCV-related.

Viral hepatitis and HIV coinfection

Hepatitis C virus (HCV) and/or hepatitis B virus (HBV) coinfection is a common finding in HIVinfected individuals [98].

Recently the use of highly active antiretroviral therapy (HAART) has led to a much longer survival of these patients, and to the emergence of different causes of death, including end-stage liver disease [99].

It is a well-known fact that HIV infection exacerbates the natural history of HCV infection [100,101].

HIV-infected patients are less likely to clear hepatitis $C$ viraemia following acute infection, have higher HCV RNA loads, and experience more rapid progression of HCV-related liver disease than those without HIV infection [98].

A meta-analysis of multiple studies assessed the correlation between HIV coinfection and the progression of HCV-related liver disease, finding a significant higher risk of developing cirrhosis and end-stage liver disease when compared with HCV monoinfection [102].

Recent observations have shown the possible direct fibrogenic action of an HIV envelope protein and this indicates an additional mechanism providing a novel molecular basis for the strong clinical evidence linking HIV/HCV coinfection with accelerated fibrogenesis.

Bruno et al [103] have recently demonstrated that gp120 exerts profibrogenic action on human HSCs in culture, identifying a direct pathway possibly linking HIV infection with liver fibrogenesis via envelope proteins. These data open up new perspectives for the management of liver diseases in HCV/ HIV-co-infected patients.

The natural history of HBV infection is also modified by HIV coinfection, which can result in higher rates of $\mathrm{HBV}$ persistence (HBsAg, $\mathrm{HBeAg}$, and $\mathrm{HBV}$ DNA detection), $\mathrm{HBV}$ relapse (reemergence of $\mathrm{HBsAg}$, HBeAg, or HBV DNA) and increased risk of liver-related morbidity and mortality [104-106].

Impact of AART on liver fibrosis in coinfected patients

$\mathrm{HCV}$

Studies on the effect of ART on the natural history of chronic HCV disease have been contradictory [107,108]. Qurishi et al reported a lower risk of liver mortality in persons who lived long enough to receive effective ART [109]. However, several prospective studies have not detected a beneficial effect of ART on HCV disease [110,111].

In other studies, ART has been associated with hepatic injury (e.g., hepatocellular necrosis and steatosis) [112,113]. Indeed, in a large cohort of HIV-infected patients, Weber et al observed an increased risk of liver-related mortality with longer ART exposure [114].

In some studies, the risk of ART-associated hepatotoxicity is greater in coinfected persons with advanced hepatic fibrosis, suggesting that liver disease staging prior to initiating ART may be useful to stratify the risk of hepatotoxicity [115].

Interestingly, effective treatment of HCV infection has been associated with reduced risk of ARTassociated liver injury [116].

$H B V$

The effect of antiretroviral-related immune restoration has been associated with spontaneous recovery from chronic HBV infection but, in other studies, with flares of hepatitis B. More recently, Puoti and coworkers observed that exposure to lamivudine containing ART has associated with decreased risk of liver-related death in $\sim 2000$ HBV/HIV coinfected persons [117]. Similarly, Miailhes and colleagues reported that 12 of 82 coinfected persons who received ART experienced seroconversion to anti-HBe and/or anti-HBs [118]. While there are emerging data to suggest that antiretroviral regimens that contain drugs active against $\mathrm{HBV}$ infection (e.g.tenofovir, emtricitabine, and lamivudine) may modify the natural history of HBV disease in HIV-infected persons by slowing disease progression and, in some patients, leading to seroconversion, additional long-term follow-up is needed to evaluate the effect of dual treatment. 


\section{Discussion}

The evaluation of liver fibrosis and its staging is essential in the management of chronic viral hepatitis. Indeed, liver biopsy is currently required before starting anti-viral therapy. Furthermore. the histological evaluation of fibrosis and necroinflammation has been used for the evaluation of impact of anti-viral therapy on liver damage.

Available evidence indicates the important role of anti-viral treatment on the improvement of histological findings in patients with chronic viral hepatitis.

In chronic HBV setting, seroconversion to antibody to HBeAg (anti-HBe) and suppression of viral replication are followed by a significant improvement of disease activity and fibrosis. HBsAg loss during Interferon based therapy is a clinically important event that is associated with improved survival and a lower risk for hepatocellular carcinoma in patients with cirrhosis. Histological improvement is obtained with all analogues treatment, achieving the value of $72 \%$ with entecavir and tenofovir.

The objective of therapy in patients with chronic hepatitis $C$ is hence to inhibit viral replication in order to decrease liver necroinflammation, which in turn is directly related to development of cirrhosis and occurrence of HCC.

This reviews shows that the benefit of interferon treatment on fibrosis progression is clinically significant in patients with advanced fibrosis by the reduction of fibrosis progression to cirrhosis. Patients treated with IFN based therapy showed a significant reduction in the rate of progression to cirrhosis and development of HCC in sustained viral responders as compared to non-responders or relapsers.

In the next future the use of the new promising directly anti-viral agents may represent an important perspective for the treatment of chronic hepatits $C$ and more data on the impact of these drugs on liver necroinflammation and fibrosis will be available in the next years.

\section{Practice points}

- HBsAg loss is a clinically important event that is associated with improved survival and a lower risk for hepatocellular carcinoma in patients with cirrhosis.

- Treatment with oral analogues retard the progression of fibrosis, reverse both fibrosis and cirrhosis, salvage patients with decompensated chronic hepatitis B and prevent hepatic decompensation in patients with advanced fibrosis and cirrhosis.

- In chronic hepatitis B, even clearing HBsAg, HBV remains in infected hepatocytes in the form of covalently closed circular DNA (cccDNA) for the lifetime thus making it possible for reactivation to occur.

- In patients with chronic hepatitis C, obesity, iron overload, environmental factors and NASH are important determinants of disease progression.

- In chronic hepatitis C, regression of fibrosis is associated with sustained virologic response to interferon therapy.

- HIV-infected patients are less likely to clear hepatitis C viraemia following acute infection, have higher HCV RNA loads, and experience more rapid progression of HCV-related liver disease than those without HIV infection.

\section{Research agenda}

- Prospective controlled studies are necessary to define the controversial association between hepatitis B virus (HBV) mutations and progression of fibrosis and hepatocarcinogenesis.

- In the next years, further studies should be performed in order to assess the impact of the new directly anti-viral agents on liver necroinflammation and fibrosis in chronic hepatitis $\mathrm{C}$. 


\section{Conflict of interest statement}

None.

\section{References}

[1] Lavanchy D. Hepatitis B virus epidemiology, disease burden, treatment, and current and emerging prevention and control measures. J Viral Hepat 2004;11:97-107.

[2] Liaw YF, Tai DI, Chu CM, Chen TJ. The development of cirrhosis in patients with chronic type B hepatitis: a prospective study. Hepatology 1988;8:493-6.

[3] de Jongh FE, Janssen HL, de Man RA, Hop WC, Schalm SW, van Blankenstein M. Survival and prognostic indicators in hepatitis B surface antigen-positive cirrhosis of the liver. Gastroenterology 1992;103:1630-5.

[4] Fattovich G, Giustina G, Schalm SW, Hadziyannis S, Sanchez-Tapias J, Almasio P, et al. Occurrence of hepatocellular carcinoma and decompensation in western European patients with cirrhosis type B. The EUROHEP Study Group on Hepatitis B Virus and Cirrhosis. Hepatology 1995;21:77-82.

[5] Fung J, Lai CL, But D, Wong D, Cheung TK, Yuen MF. Prevalence of fibrosis and cirrhosis in chronic hepatitis B: implications for treatment and management. Am J Gastroenterol 2008;103:1421-6.

[6] Fujiwara A, Sakaguchi K, Fujioka S, Iwasaki Y, Senoh T, Nishimura M, et al. Fibrosis progression rates between chronic hepatitis B and C patients with elevated alanine aminotransferase levels. J Gastroenterol 2008;43:484-91.

[7] Nguyen MH, Garcia RT, Trinh HN, Lam KD, Weiss G, Nguyen HA, et al. Histological disease in Asian-Americans with chronic hepatitis B, high hepatitis B virus DNA, and normal alanine aminotransferase levels. Am J Gastroenterol 2009; 104:2206-13.

*[8] Fattovich G, Bortolotti F, Donato F. Natural history of chronic hepatitis B: special emphasis on disease progression and prognostic factors. J Hepatol 2008;48:335-52.

[9] Tsang PS, Trinh H, Garcia RT, Phan JT, Ha NB, Nguyen H, et al. Significant prevalence of histologic disease in patients with chronic hepatitis B and mildly elevated serum alanine aminotransferase levels. Clin Gastroenterol Hepatol 2008;6:56974 .

[10] Iloeje UH, Yang HI, Su J, et al. Predicting cirrhosis risk based on the level of circulating hepatitis B viral load. Gastroenterology 2006;130:678-86.

[11] Shao J, Wei L, Wang H, Sun Y, Zhang LF, Li J, et al. Relationship between hepatitis B virus DNA levels and liver histology in patients with chronic hepatitis B. World J Gastroenterol 2007;13:2104-7.

[12] Park JY, Park YN, Kim DY, Paik YH, Lee KS, Moon BS, et al. High prevalence of significant histology in asymptomatic chronic hepatitis B patients with genotype C and high serum HBV DNA levels. J Viral Hepat 2008;15:615-21.

[13] Wang CC, Lim LY, Deubner H, Tapia K, Lau AW, Manansala J, et al. Factors predictive of significant hepatic fibrosis in adults with chronic hepatitis B and normal serum ALT. J Clin Gastroenterol 2008;42:820-6.

[14] Walewska-Zielecka B, Madalinski K, Jablonska J, Godzik P, Cielecka-Kuszyk J, Litwinska B. Composition of inflammatory infiltrate and its correlation with HBV/HCV antigen expression. World J Gastroenterol 2008;14:4040-6.

[15] Maini MK, Boni C, Lee CK, Larrubia JR, Reignat S, Ogg GS, et al. The role of virus-specific CD8(+) cells in liver damage and viral control during persistent hepatitis B virus infection. J Exp Med 2000;191:1269-80.

[16] Das A, Hoare M, Davies N, Lopes AR, Dunn C, Kennedy PT, et al. Functional skewing of the global CD8 T cell population in chronic hepatitis B virus infection. J Exp Med 2008;205:2111-24.

[17] Dunn C, Brunetto M, Reynolds G, Christophides T, Kennedy PT, Lampertico P, et al. Cytokines induced during chronic hepatitis B virus infection promote a pathway for NK cell-mediated liver damage. J Exp Med 2007;204:667-80.

[18] Mani H, Kleiner DE. Liver biopsy findings in chronic hepatitis B. Hepatology 2009;49:S61-71.

[19] Ruiz-Moreno M, Otero M, Millán A, Castillo I, Cabrerizo M, Jiménez FJ, et al. Clinical and histological outcome after hepatitis B e antigen to antibody seroconversion in children with chronic hepatitis B. Hepatology 1999;29:572-5.

[20] Bortolotti F, Fattovich G. Host and environmental factors influencing hepatitis B e antigen seroconversion in children. J Hepatol 2008;49:1079-80.

[21] Fried MW, Piratvisuth T, Lau GK, Marcellin P, Chow WC, Cooksley G, et al. HBeAg and hepatitis B virus DNA as outcome predictors during therapy with peginterferon alfa-2a for HBeAg-positive chronic hepatitis B. Hepatology 2008;47:42834.

[22] Chen CJ, Yang HI, Su J, Jen CL, You SL, Lu SN, et al. REVEAL-HBV Study Group. Risk of hepatocellular carcinoma across a biological gradient of serum hepatitis B virus DNA level. JAMA 2006;295:65-73.

[23] Feld JJ, Wong DKW, Heathcote EJ. Endpoints of therapy in chronic hepatitis B. Hepatology 2009;49:S96-102.

[24] Rang A, Bruns M, Heise T, Will H. Antiviral activity of interferon- $\alpha$ against hepatitis B virus can be studied in non-hepatic cells and is independent of MxA. J Biol Chem 2002;277:7645-7.

[25] Perrillo R. Benefits and risks of interferon therapy for hepatitis B. Hepatology 2009;49:S103-11.

[26] Janssen HL, van Zonneveld M, Senturk H, Zeuzem S, Akarca US, Cakaloglu Y, et al. Pegylated interferon alfa-2b alone or in combination with lamivudine for HBeAg-positive chronic hepatitis B: a randomised trial. Lancet 2005;365:123-9.

[27] Lau GK, Piratvisuth T, Luo KX, Marcellin P, Thongsawat S, Cooksley G, et al. Peginterferon alfa-2a, lamivudine, and the combination for HBeAg positive chronic hepatitis B. N Engl J Med 2005;352:2682-95.

*[28] Marcellin P, Lau GK, Bonino F, Farci P, Hadziyannis S, Jin R, et al. Peginterferon alfa-2a alone, lamivudine alone, and the two in combination in patients with HBeAg-negative chronic hepatitis B. N Engl J Med 2004;351:1206-17.

[29] Lampertico P, Del Ninno E, Viganò M, Romeo R, Donato MF, Sablon E, et al. Long-term suppression of hepatitis B e antigen-negative chronic hepatitis B by 24-month interferon therapy. Hepatology 2003;37:756-63.

[30] Manensis EK, Hadziyannis SJ. Interferon alpha treatment and retreatment of hepatitis B e antigen- negative chronic hepatitis B. Gastroenterology 2001;121:101-9.

[31] Dienstag JL, Schiff ER, Wright TL, Perrillo RP, Hann HW, Goodman Z, et al. Lamivudine as initial treatment for chronic hepatitis B in the United States. N Engl J Med 1999;341:1256-63. 
[32] Marcellin P, Chang TT, Lim SG, Tong MJ, Sievert W, Shiffman ML, et al. Adefovir dipivoxil for the treatment of hepatitis B e antigen-positive chronic hepatitis B. N Engl J Med 2003;348:808-16.

[33] Hadziyannis SJ, Tassopoulos NC, Heathcote EJ, Chang TT, Kitis G, Rizzetto M, et al. Adefovir dipivoxil for the treatment of hepatitis B e antigen-negative chronic hepatitis B. N Engl J Med 2003;348:800-7.

[34] Dienstag JL, Goldin RD, Heathcote EJ, Hann HW, Woessner M, Stephenson SL, et al. Histological outcome during longterm lamivudine therapy. Gastroenterology 2003;124:105-17.

[35] Kweon YO, Goodman ZD, Dienstag JL, Schiff ER, Brown NA, Burchardt E, et al. Decreasing fibrogenesis: an immunohistochemical study of paired liver biopsies following lamivudine therapy for chronic hepatitis B. J Hepatol 2001;35: 749-55.

[36] Malekzadeh R, Mohamadnejad M, Rakhshani N, Nasseri-Moghaddam S, Merat S, Tavangar SM, et al. Reversibility of cirrhosis in chronic hepatitis B. Clin Gastroenterol Hepatol 2004;2:344-7.

[37] Yao FY, Bass NM. Lamivudine treatment in patients with severely decompensated cirrhosis due to replicating hepatitis B infection. J Hepatol 2000;33:301-7.

[38] Yao FY, Terrault NA, Freise C, Maslow L, Bass NM. Lamivudine treatment is beneficial in patients with severely decompensated cirrhosis and actively replicating hepatitis B infection awaiting liver transplantation: a comparative study using a matched, untreated cohort. Hepatology 2001;34:411-6.

[39] Fontana RJ, Keeffe EB, Carey W, Fried M, Reddy R, Kowdley KV, et al. Effect of lamivudine treatment on survival in 309 North American patients awaiting liver transplantation for chronic hepatitis B. Liver Transpl 2002;8:433-9.

[40] Liaw YF, Sung JJ, Chow WC, Farrell G, Lee CZ, Yuen H, et al. Lamivudine for patients with chronic hepatitis B and advanced liver disease. N Engl J Med 2004;351:1521-31.

[41] Chang TT, Lai CL, Chien RN, Guan R, Lim SG, Lee CM, et al. Four years of lamivudine treatment in Chinese patients with chronic hepatitis B. J Gastroenterol Hepatol 2004;19:1276-82.

[42] Perrillo R, Hann HW, Mutimer D, Willems B, Leung N, Lee WM, et al. Adefovir dipivoxil added to ongoing lamivudine in chronic hepatitis B with YMDD mutant hepatitis B virus. Gastroenterology 2004;126:81-90.

[43] Peters MG, Hann Hw H, Martin P, Heathcote EJ, Buggisch P, Rubin R, et al. Adefovir dipivoxil alone or in combination with lamivudine in patients with lamivudine-resistant chronic hepatitis B. Gastroenterology 2004;126:91-101.

[44] Schiff ER, Lai CL, Hadziyannis S, Neuhaus P, Terrault N, Colombo M, et al. Adefovir dipivoxil therapy for lamivudineresistant hepatitis B in pre and post-liver transplantation patients. Hepatology 2003;38:1419-27.

[45] Fung SK, Chae HB, Fontana RJ, Conjeevaram H, Marrero J, Oberhelman K, et al. Virologic response and resistance to adefovir in patients with chronic hepatitis B. J Hepatol 2006;44:283-90.

[46] Chang TT, Gish RG, de Man R, Gadano A, Sollano J, Chao YC, et al. A comparison of entecavir and lamivudine for HBeAgpositive chronic hepatitis B. N Engl J Med 2006;354:1001-10.

*[47] Lai CL, Shouval D, Lok AS, Chang TT, Cheinquer H, Goodman Z, et al. Entecavir versus lamivudine for patients with HBeAg-negative chronic hepatitis B. N Engl J Med 2006;354:1011-20.

*[48] Chang TT, Liaw YF, Wu SS, Schiff E, Han KH, Lai CL, et al. Long-term entecavir therapy results in the reversal of fibrosis/ cirrhosis and continued histological improvement in patients with chronic hepatitis B. Hepatology 2010;52(3):886-93.

[49] Liaw YF, Gane E, Leung N, Zeuzem S, Wang Y, Lai CL, et al. 2-Year GLOBE Trial results: telbivudine is superior to lamivudine in patients with chronic hepatitis B. Gastroenterology 2009;136:486-95.

[50] Marcellin P, Heathcote EJ, Buti M, Gane E, de Man RA, Krastev Z, et al. Tenofovir disoproxil fumarate versus adefovir dipivoxil for chronic hepatitis B. N Engl J Med 2008;359:2442-55.

*[51] Heathcote EJ, Marcellin P, Buti M, Gane E, De Man RA, Krastev Z, et al. Three-Year Efficacy and Safety of Tenofovir Disoproxil Fumarate Treatment for Chronic Hepatitis B. Gastroenterology; 2010.

[52] Fattovich G, Pantalena M, Zagni I, Realdi G, Schalm SW, Christensen E. European Concerted Action on Viral Hepatitis (EUROHEP). Effect of hepatitis B and C virus infections on the natural history of compensated cirrhosis: a cohort study of 297 patients. Am J Gastroenterol 2002;97:2886-95.

[53] Serfaty L, Aumaitre H, Chazouilleres O, Bonnand AM, Rosmorduc O, Poupon RE, et al. Determinants of outcome of compensated hepatitis C virus-related cirrhosis. Hepatology 1998;27:1435-40.

[54] Hu KQ Tong MJ. The long-term outcomes of patients with compensated hepatitis C virus-related cirrhosis and history of parenteral exposure in the United States. Hepatology 1999;29:1311-6.

[55] Benvegnu' L, Gios M, Boccato S, Alberti A. Natural history of compensated viral cirrhosis: a prospective study on incidence and hierachy of major complications. Gut 2004;37:744-9.

[56] Fattovich G, Giustina G, Degos F, Diodati G, Tremolada F, Almasio P, et al. Morbidity and mortality in compensated cirrhosis type C: a retrospective follow up study of 384 patients. Gastroenterology 1997;112:463-72.

[57] World Health Organization Fact Sheet. http://www.who.int/mediacentre/factsheets/fs164/en/print.html.

[58] Kuo G, Choo QL, Alter HJ, Gitnick GL, Redeker AG, Purcell RH, et al. An assay for circulating antibodies to a major etiologic virus of human non-A, non-B hepatitis. Science 1989;244:362-4.

[59] Persico M, Persico E, Suozzo R, Conte S, De Seta M, Coppola L, et al. Natural history of hepatitis C virus carriers with persistently normal aminotransferase levels. Gastroenterology 2000;118:760-4.

[60] Roffi L, Ricci A, Ogliari C, Scalera A, Minola E, Colloredo G, et al. HCV genotype in Northern Italy: a survey of 1368 histologically proven chronic hepatitis C patients. J Hepatol 1998;29:701-6.

[61] Zeuzem S, Franke A, Lee JH, Herrmann G, Ruster B, Roth WK. Phylogenetic analysis of hepatitis C virus isolates and their correlation to viremia, liver function tests, and histology. Hepatology 1996;24:1003-9.

[62] Bruno S, Crosignani A, Maisonneuve P, Rossi S, Silini E, Mondelli MU. Hepatitis C virus genotype 1b as a major risk factor associated with hepatocellular carcinoma in patients with cirrhosis: a seventeen-year prospective cohort study. Hepatology 2007;46:1350-6.

[63] Soto B, Sanchez-Quijano A, Rodrigo L, del Olmo JA, Garcia-Bengoechea M, Hernandez-Quero J, et al. Human immunodeficiency virus infection modifies the natural history of chronic parenterally acquired hepatitis $C$ with an unusually rapid progression to cirrhosis. J Hepatol 1997;26:1-5.

[64] Pontisso P, Gerotto M, Benvegnù L, Chemello L, Alberti A. Coinfection by hepatitis B virus and hepatitis C virus. Antivir Ther 1998;3:137-42. 
[65] Sterling RK, Sulkowski MS. Hepatitis C virus in the setting of HIV or hepatitis B virus coinfection. Semin Liver Dis 2004; 24(Suppl. 2):61-78.

[66] Tong MJ, el-Farra NS, Reikes AR, Co RL. Clinical outcomes after transfusion-associated hepatitis C. N Engl J Med 1995; 332:1463-6.

[67] Bellentani S, Tiribelli C. The spectrum of liver disease in the general population: lesson from the Dionysos study. J Hepatol 2001;35:531-7.

*[68] Poynard T, Bedossa P, Opolon P. Natural history of liver fibrosis progression in patients with chronic hepatitis C. The OBSVIRC, METAVIR, CLINIVIR, and DOSVIRC groups. Lancet 1997;349:825-32.

[69] Corrao G, Aricò S, Ascione A. Epidemiology of chronic liver disease in Italy. Ital J Gastroenterol 1994;26:44-9.

[70] Peters MG, Terrault NA. Alcohol use and hepatitis C. Hepatology 2002;36(Suppl. 1):S220-5.

[71] Ortiz V, Berenguer M, Rayón JM, Carrasco D, Berenguer J. Contribution of obesity to hepatitis C-related fibrosis progression. Am J Gastroenterol 2002;97:2408-14.

[72] Monto A. Hepatitis C and steatosis. Semin Gastrointest Dis 2002;13:40-6.

[73] D'Souza R, Sabin CA, Foster GR. Insulin resistance plays a significant role in liver fibrosis in chronic hepatitis C and in the response to antiviral therapy. Am J Gastroenterol 2005;100:1509-15.

[74] Thorburn D, Curry G, Spooner R, Spence E, Oien K, Halls D, et al. The role of iron and haemochromatosis gene mutations in the progression of liver disease in chronic hepatitis C. Gut 2002;50:248-52.

[75] Poynard T, Mathurin P, Lai CL, Guyader D, Poupon R, Tainturier MH, et alPANFIBROSIS Group. A comparison of fibrosis progression in chronic liver diseases. J Hepatol 2003;38:257-65.

[76] Corrao G, Aricò S. Independent and combined action of hepatitis C virus infection and alcohol consumption on the risk of symptomatic liver cirrhosis. Hepatology 1998;27:914-9.

[77] Seeff LB. Natural history of chronic hepatitis C. Hepatology 2002;36(Suppl. 1):S35-46.

[78] Tremolada F, Casarin C, Alberti A, Drago C, Tagger A, Ribero ML, et al. Long-term follow-up of non-A, non-B (type C) posttransfusion hepatitis. J Hepatol 1992;16:273-81.

[79] D’Amico G, Garcia-Tsao G, Pagliaro L. Natural history and prognostic indicators of survival in cirrhosis: a systematic review of 118 studies. J Hepatol 2006;44:217-31.

*[80] Shiratori Y, Imazeki F, Moriyama M, Yano M, Arakawa Y, Yokosuka O, et al. Histologic Improvement of Fibrosis in Patients with Hepatitis C Who Have Sustained Response to Interferon Therapy. Ann Intern Med 2000;132:517-24.

[81] Veldt BJ, Saracco G, Boyer N, Cammà C, Bellobuono A, Hopf U, et al. Long term clinical outcome of chronic hepatitis C patients with sustained virological response to interferon monotherapy. Gut 2004;53:1504-8.

[82] Cammà C, Di Bona D, Schepis F, Heathcote EJ, Zeuzem S, Pockros PJ, et al. Effect of peginterferon alfa-2a on liver histology in chronic hepatitis C: a meta-analysis of individual patient data. Hepatology 2004;39:333-42.

[83] Poynard T, McHutchison J, Manns M, Trepo C, Lindsay K, Goodman Z, et al. Impact of pegylated interferon alfa-2b and ribavirin on liver fibrosis in patients with chronic hepatitis C. Gastroenterology 2002;122:1303-13.

*[84] George SL, Bacon BR, Brunt EM, Mihindukulasuriya KL, Hoffmann J, Di Bisceglie AM. Clinical, Virologic, Histologic, and Biochemical Outcomes After Successful HCV Therapy: A 5-Year Follow-up of 150 Patients. Hepatology 2009;49:729-38.

[85] Marcellin P, Boyer N, Degott C, Martinot-Peignoux M, Duchatelle V, Giostra E, et al. Long term histological and viral changes in patients with chronic hepatitis C who responded to $\alpha$-interferon. Liver 1994;14:302-7.

[86] Sata M, Ide T, Akiyoshi F, Fukuizumi K, Noguchi S, Shirachi M, et al. Effects of interferon alpha 2a on incidence of hepatocellular carcinoma in chronic active hepatitis without cirrhosis. Hepatitis Treatment Study Group. Kurume Med J 1997;44:171-7.

[87] Veldt BJ, Heathcote EJ, Wedemeyer H, Reichen J, Hofmann WP, Zeuzem S, et al. Sustained virologic response and clinical outcomes in patients with chronic hepatitis $C$ and advanced fibrosis. Ann Intern Med 2007;147:677-84.

[88] Yoshida H, Arakawa Y, Sata M, Nishiguchi S, Yano M, Fujiyama S, et al. Interferon therapy prolonged life expectancy among chronic hepatitis C patients. Gastroenterology 2002;123:483-91.

[89] Shiratori Y, Ito Y, Yokosuka O, Imazeki F, Nakata R, Tanaka N. Tokyo-Chiba Hepatitis Research Group. Antiviral therapy for cirrhotic hepatitis C: association with reduced hepatocellular carcinoma development and improved survival. Ann Intern Med 2005;142:105-14.

[90] Di Marco V, Almasio PL, Ferraro D, Calvaruso V, Alaimo G, Peralta S, et al. Peg-interferon alone or combined with ribavirin in HCV cirrhosis with portal hypertension: a randomized controlled trial. J Hepatol 2007;47:484-91.

[91] Bruno S, Crosignani A, Facciotto C, Rossi S, Roffi L, Redaelli A, et al. Sustained virologic response prevents the development of esophageal varices in compensated, Child-Pugh class A hepatitis C virus-induced cirrhosis. A 12-year prospective follow-up study. Hepatology 2010 Jun;51(6):2069-76.

[92] Rincon D, Ripoll C, Lo Iacono O, Salcedo M, Catalina MV, Alvarez E, et al. Antiviral therapy decreases hepatic venous pressure gradient in patients with chronic hepatitis C and advanced fibrosis. Am J Gastroenterol 2006;101:2269-74.

[93] Roberts S, Gordon A, McLean C, Pedersen J, Bowden S, Thomson K, et al. Effect of sustained viral response on hepatic venous pressure gradient in hepatitis C-related cirrhosis. Clin Gastroenterol Hepatol 2007;5:932-7.

[94] Maylin S, Martinot-Peignoux M, Moucari R, Boyer N, Ripault MP, Cazals-Hatem D, et al. Eradication of hepatitis C virus in patients successfully treated for chronic hepatitis C. Gastroenterology 2008;135:821-9.

[95] Mallet V, Gilgenkrantz H, Serpaggi J, Verkarre V, Vallet-Pichard A, Fontaine H, et al. Brief communication: the relationship of regression of cirrhosis to outcome in chronic hepatitis C. Ann Intern Med 2008;149:399-403.

[96] Bruno S, Stroffolini T, Colombo M, Bollani S, Benvegnù L, Mazzella G, et al. Sustained virological response to interferonalpha is associated with improved outcome in HCV-related cirrhosis: a retrospective study. Hepatology 2007;45:579-87.

*[97] Bruno S, Stroffolini T, Colombo M, Bollani S, Benvegnù L, Mazzella G, et al. Impact of peginterferon and ribavirin therapy on hepatocellular carcinoma: incidence and survival in hepatitis C patients with advanced fibrosis. J Hepatol 2010 May; 52(5):652-7.

[98] Sulkowski MS. Viral hepatitis and HIV coinfection. J Hepatol 2008;48:353-67.

[99] Bonacini M. Diagnosis and management of cirrhosis in coinfected patients. J Acquir Immune Defic Syndr 2007;45:S38-46.

[100] Eyster ME, Diamondstone LS, Lien JM, Ehmann WC, Quan S, Goedert JJ. Natural history of hepatitis C virus infection in multitransfused hemophiliacs: effect of coinfection with human immunodeficiency virus. The Multicenter Hemophilia Cohort Study. J Acquir Immune Defic Syndr 1993;6:602-10. 
[101] Pol S, Lamorthe B, Thi NT, Thiers V, Carnot F, Zylberberg H, et al. Retrospective analysis of the impact of HIV infection and alcohol use on chronic hepatitis C in a large cohort of drug users. J Hepatol 1998;28:945-50.

[102] Graham CS, Baden LR, Yu E, Mrus JM, Carnie J, Heeren T, et al. Influence of human immunodeficiency virus infection on the course of hepatitis c virus infection: a meta-analysis. Clin Infect Dis 2001;33:562-9.

*[103] Bruno R, Galastri S, Sacchi P, Cima S, Caligiuri A, DeFranco R, et al. gp120 modulates the biology of human hepatic stellate cells: a link between HIV infection and liver fibrogenesis GUT 2010;59:513-20.

[104] Kellerman SE, Hanson DL, McNaghten AD, Fleming PL. Prevalence of chronic hepatitis B and incidence of acute hepatitis B infection in human immunodeficiency virus-infected subjects. J Infect Dis 2003;188:571-7.

[105] Alter MJ. Epidemiology of viral hepatitis and HIV co-infection. J Hepatol 2006;44:S6-9.

[106] Bodsworth N, Donovan B, Nightingale BN. The effect of concurrent human immunodeficiency virus infection on chronic hepatitis B: a study of 150 homosexual men. J Infect Dis 1989;160:577-82.

[107] Benhamou Y, Di Martino V, Bochet M, Colombet G, Thibault V, Liou A, et al. Factors affecting liver fibrosis in human immunodeficiency virus-and hepatitis $C$ virus-coinfected patients: impact of protease inhibitor therapy. Hepatology $2001 ; 34: 283-7$.

[108] Macías J, Castellano V, Merchante N, Palacios RB, Mira JA, Sáez C, et al. Effect of antiretroviral drugs on liver fibrosis in HIV-infected patients with chronic hepatitis C: harmful impact of nevirapine. AIDS 2004;18:767-74.

[109] Qurishi N, Kreuzberg C, Rockstroh JK, Spengler U. Effect of antiretroviral therapy on liver-related mortality in patients with HIV and hepatitis C coinfection. Lancet 2004;362:1708-13.

[110] Mehta SH, Thomas DL, Torbenson M, Brinkley S, Mirel L, Chaisson RE, et al. The effect of antiretroviral therapy on liver disease among adults with HIV and hepatitis C coinfection. Hepatology 2005;41:123-31.

[111] Mocroft A, Soriano V, Rockstroh J, Reiss P, Kirk O, de Wit S, et al. Is there evidence for an increase in the death rate from liver-related disease in patients with HIV? AIDS 2005;19:2117-25.

[112] Maida I, Núñez M, Ríos MJ, Martín-Carbonero L, Sotgiu G, Toro C, et al. Severe liver disease associated with prolonged exposure to antiretroviral drugs. J Acquir Immune Defic Syndr 2006;42:177-82.

[113] Sulkowski MS, Mehta SH, Torbenson M, Afdhal NH, Mirel L, Moore RD, et al. Hepatic steatosis and antiretroviral drug use among adults coinfected with HIV and hepatitis C virus. AIDS 2005;19:585-92.

[114] Weber R, Sabin CA, Friis-Møller N, Reiss P, El-Sadr WM, Kirk O, et al. Liver-related deaths in persons infected with the human immunodeficiency virus: the D: A:D study. Arch Intern Med 2006;166:1632-41.

[115] Aranzabal L, Casado JL, Moya J, Quereda C, Diz S, Moreno A, et al. Influence of liver fibrosis on highly active antiretroviral therapy-associated hepatotoxicity in patients with HIV and hepatitis C virus coinfection. Clin Infect Dis 2005;40:588-93.

[116] Soriano V, Puoti M, Sulkowski M, Cargnel A. Benhamou Y, Peters M, et al. Care of patients coinfected with HIV and hepatitis C virus: 2007 updated recommendations from the HCV-HIV International Panel. AIDS 2007;21:1073-89.

[117] Puoti M, Cozzi-Lepri A, Paraninfo G, Arici C, Moller NF, Lundgren JD, et al. Impact of lamivudine on the risk of liver related death in $2041 \mathrm{HBsAg}$ and HIV-positive individuals: results from an inter-cohort analysis. Antivir Ther 2006;11:567-74.

[118] Miailhes P, Trabaud MA, Pradat P, Lebouché B, Chevallier M, Chevallier P, et al. Impact of highly active antiretroviral therapy (HAART) on the natural history of hepatitis B virus (HBV) and HIV coinfection: relationship between prolonged efficacy of HAART and HBV surface and early antigen seroconversion. Clin Infect Dis 2007;45:624-32. 